\title{
Evaluation of problematic use of mobile phones and quality of sleep among high school students ${ }^{1}$
}

\author{
Fatih Öz $z^{2}$ \\ Didem Arslantaş ${ }^{3}$ \\ Necati Buğrul ${ }^{4}$ \\ Tuğçe Koyuncu ${ }^{5}$ \\ Alaettin Ünsal ${ }^{6}$
}

\begin{abstract}
It was aimed to evaluate the problematic use of mobile phones and quality of sleep among high school students. This is a cross-sectional study carried out on 1,131 high school students studying at Sivrihisar, a district of Eskisehir, in December 2012. The questionnaire form include the sociodemographic characteristics, problematic use of mobile phones and quality of sleep. BianchiPhillips problematic use of mobile phones (PUMP) scale and Pittsburgh Sleep Quality Index (PSQI) was used. Median score of PUMP was higher in students using cigarette, using headphones, having a lover and changing the mobile phone frequently ( $\mathrm{p}<0.05$ for each). Quality of sleep was found to decline with increasing median scores on PUMP scale.

Results of the present study suggest that problematic use of mobile phones declines the quality of life among high school students from Sivrihisar. Adolescents and their family should be informed about use of mobile phones.
\end{abstract}

Keywords: Problematic use of mobile phones, Quality of sleep, High school students

\section{Introduction}

With the recent advances in technology, tools such as computers, internet and mobile phones are now affecting the lives of people profoundly in many areas. Because mobile phones offer many different functions including communication with the family members or others,

\footnotetext{
1 This study was presented as oral presentations at the $4^{\text {th }}$ quality of life in health congress in Izmir.

2 Research Assistant, Eskisehir Osmangazi University, Medical Faculty Department of Public Health ozzfatih@hotmail.com

3 Prof. Dr, Eskisehir Osmangazi University, University, Medical Faculty Department of Public Health darslantas@yahoo.com

4 Research Assistant, Eskisehir Osmangazi University, Medical Faculty Department of Public Health nbugrul@hotmail.com

5 Research Assistant, Eskisehir Osmangazi University, Medical Faculty Department of Public Health tkoyuncu@,ogu.edu.tr

6 Prof. Dr, Eskisehir Osmangazi University, Medical Faculty Department of Public Health alaattin@ogu.edu.tr
} 
Öz, F., Arslantaş, D., Buğrul, N., Koyuncu, T., \& Ünsal, A. (2015). Evaluation of problematic use of mobile phones and quality of sleep among high school students. International Journal of Human Sciences, 12(1), 226-235. doi: $\underline{10.14687 / \text { ijhs.v12i1.3122 }}$

connection to the internet or social networks, playing games, and listening to music, it becomes an indispensable tool in daily living. According to the 2013 data of Turkish Statistical Institute (TSI), the prevalence of having a mobile phone is $90.7 \%$ in Turkey, indicating the major role of mobile phones in our lives. This figure also triggers the problematic use of mobile phones and results in unlimited use of mobile phones at a dependency degree (TUIK, 2014). Problematic use of mobile phones represents a new term which implies as feeling unsafe in daily living when not having a mobile phone and spending much time with the mobile phone at a degree affecting the daily life negatively (Eggermont \& Van den Bulck, 2006).

New-generation mobile phones are now designed to include all multimedia applications. Because of offering the functions of $\mathrm{mp} 3$ player, camera, video recording, internet connection and game player, the age of the mobile phone use is gradually reduced. In our country, mobile phone market came into prominence considerably in 1990s, with increasing the market space and becoming one of the major markets after 2000. Advanced technology for mobile phones is now used not only by people with a high socio-economic level but also by those with a moderate- or low-socioeconomic level (Özcan \& Koçak, 2003). Today, in Turkey, mobile phones are considered as a symbol of modernity by some people (Çelik, 2011). The active subscribers of Turkish GSM operators are increasing in number and the young population of Turkey has been suggested to have a significant potential for the development of the market (Özaydın, 2010).

Sleeping is one of the basic necessities of the human being and is very important for a healthy life and to maintain the quality of life at all ages. Sleeping is a basic element for the physical growth and improving the academic performance, with being much more important in the young age and adolescence (Öztürk, 2002). Sleep quality and sleep hygiene are among the major behaviors that should be addressed in order to facilitate the growth, development and psychosocial development and to increase health quality and quality of life. It has been suggested that people having sleep problems experience more problems in daily living, decrease in quality of life and dissipation of energy (Khan, 2004). Sleep quality is feeling fit, form and ready for a new day when waking up in the morning. There are many factors affecting the sleep quality including lifestyle, environmental factors, work and social lives, economic status, general health status and stressful events. Also, the habits of the individual, family structure, use of medication, cognitive status, and ignorant use of the technology (internet, mobile phone, TV etc.) have been suggested to influence the sleep quality (Şenol, Soyuer, Akça, \& Argün, 2012). 
Öz, F., Arslantaş, D., Buğrul, N., Koyuncu, T., \& Ünsal, A. (2015). Evaluation of problematic use of mobile phones and quality of sleep among high school students. International Journal of Human Sciences, 12(1), 226-235. doi: $\underline{10.14687 / \text { ijhs.v12i1.3122 }}$

Present study aimed to determine the prevalence of problematic use of mobile phones and to assess the sleep quality and associated factors among the high school students studying at the Sivrihisar district.

\section{Methods}

This is a cross-sectional study carried out on 1,131 high school students studying at Sivrihisar, a district of Eskisehir, in November-December 2012. Sivrihisar is a district located in the east of Eskisehir and is approximately $90 \mathrm{~km}$ from the city center.

There were a total of 1340 students studying at the 8 high schools in Sivrihisar (Nurbiye Gulerce Health Vocational High School, Sivrihisar Anatolian Technical and Industrial Vocational High School, Sivrihisar Education Foundation Muzaffer Demir Anatolian High School, Sidıka Hanım High School, Sivrihisar Anatolian Teacher-Training High School, Vocational High School for Girls, Imam Hatip High School and Sivrihisar Trade Vocational High School).

The questionnaire form prepared for the purpose of the study includes some sociodemographic characteristics (age, gender, school, class, disability status, maternal-paternal state of being alive, togetherness of the parents, maternal-paternal education level, profession of parents, economic status of the family, number of siblings, family structure, state of having a lover, the number of family members having a mobile phone, the age of getting a mobile phone, the reason for having a mobile phone, the most frequently communicated person by phone, phone line, use of headphones, frequency of changing the mobile phone, reason for buying a mobile phone, smoking status and status or having a mobile phone or not), the problematic use of mobile phones (PUMP) scale developed by Bianchi and Phillips to evaluate the mobile phone addiction and the Pittsburgh Sleep Quality Index (PSQI).

Before collection of data, the necessary permissions were obtained from Town Directorate of National Education. Students were gathered in their classrooms at the date and hour predetermined by the school administrators and researchers. After giving information about the subject and purpose of the study, informed consent was obtained from all students. The preprepared questionnaire form was filled out by the students under supervision in about 20-25 min. A total of 209 students (15.6) who were not at the school during the study period and who gave incomplete or erroneous information were excluded from the study, leaving 1131 students (84.4\%) to constitute the study group. Because $111(9.8 \%)$ students had no mobile phones, PUMP scale was used in $1020(90.2 \%)$ students. 
Öz, F., Arslantaş, D., Buğrul, N., Koyuncu, T., \& Ünsal, A. (2015). Evaluation of problematic use of mobile phones and quality of sleep among high school students. International Journal of Human Sciences, 12(1), 226-235. doi: $\underline{10.14687 / \text { ijhs.v12i1.3122 }}$

PUMP scale developed by Bianchi and Phillips is a 5-Likert type scale comprised of 27 items with a total score ranging from 27 to 135 . The higher score indicates higher problematic use of the mobile phones (Bianchi \& Phillips, 2005). The reliability and validity of the Turkish version of the scale were established in 2012 by Sar et al (Sar \& Iş1klar, 2012). Pittsburgh Sleep Quality Index (PSQI) used for the assessment of sleep quality has been developed by Buysse et al (1989) and translated into Turkish by Agargun et al (1996). PSQI assesses the sleep quality and sleep disorders in the past month. The index includes 24 items, of which 19 are based on self-report and the remaining 5 are answered by the spouse or roommate. The 18 scored items in the scale has 7 components including Subjective Sleep Quality, Sleep latency, Sleep Duration, Sleep efficiency, Sleep Disturbance, Use of the sleep medication, and the Daytime Dysfunction. Each component is scored between 0 and 3, with a total score ranging between 0 and 21. A total score of 5 or higher indicates a poor sleep quality (Buysse, Reynolds III, Monk, Berman, \& Kupfer, 1989), (Ağargün, Kara, \& Anlar, 1996).

Self-reported family income level was graded as satisfactory, moderate or poor. Students smoking at least 1 cigarette daily were considered as smoker. It was considered as a nuclear family if the family includes only the parents and siblings and as a patriarchal family if the family also includes first degree relatives (maternal/paternal grandmothers, grandfathers, uncles or aunts).

The data were analyzed on computer by using SPSS 15.0 Statistical Package Program. MannWhitney U, Kruskal-Wallis and Spearman Correlation tests were used for the statistical analysis. Significance level was set at $\mathrm{P}<0.05$.

\section{Results}

The study group included $544(53.4 \%)$ female and 476 (46.6\%) male students. The mean age was $15.8 \pm 1.13$ years (range, 13-20 years). A total of 201 students $(19.7 \%$ ) were studying at Anatolian Teacher Training High School. The paternal education level was secondary school or higher for 571 students $(56.0 \%)$ and primary school or lower for 449 students (44.0\%). Of the study participants, $314(31.7 \%)$ had a lover and these students had a higher median PUMP score. The mean PUMP score was also higher in smokers and students using headphones. Of the students using a mobile phone, $408(40 \%)$ used the mobile phones for more than one purposes, while $263(25.7 \%)$ were using only for sending and receiving text messages. The distribution of median PUMP scores by come sociodemographic characteristics are given in Table 1. 
Öz, F., Arslantaş, D., Buğrul, N., Koyuncu, T., \& Ünsal, A. (2015). Evaluation of problematic use of mobile phones and quality of sleep among high school students. International Journal of Human Sciences, 12(1), 226-235. doi: $\underline{10.14687 / \text { ijhs.v12i1.3122 }}$

Table 1. The distribution of median PUMP scores by come sociodemographic characteristics

\begin{tabular}{|c|c|c|c|}
\hline $\begin{array}{l}\text { Sociodemographic } \\
\text { characteristics }\end{array}$ & $\mathbf{n}$ & $\begin{array}{c}\text { PUMP score } \\
\text { Median (min-max) }\end{array}$ & $\begin{array}{l}\text { Test value } \\
\mathrm{z} / \mathrm{KW} ; \mathrm{p}\end{array}$ \\
\hline \multicolumn{4}{|l|}{ Age group } \\
\hline$\leq 15$ years & 431 & $44.0(27-135)$ & \multirow[t]{2}{*}{$2.365 ; 0.018$} \\
\hline$\geq 16$ years & 589 & $47.0(27-135)$ & \\
\hline \multicolumn{4}{|l|}{ Gender } \\
\hline Female & 544 & $45.0(27-123)$ & \multirow{2}{*}{$2.054 ; 0.040$} \\
\hline Male & 476 & $48.0(27-135)$ & \\
\hline \multicolumn{4}{|l|}{ School } \\
\hline $\begin{array}{l}\text { Vocational High School for } \\
\text { Girls }\end{array}$ & 127 & $43.0(27-119)$ & \multirow{8}{*}{$45.771 ; 0.000$} \\
\hline $\begin{array}{lll}\text { Industrial Vocational High } \\
\text { School }\end{array}$ & 198 & $55.5(27-135)$ & \\
\hline $\begin{array}{l}\text { Muzaffer Demir Anatolian } \\
\text { High School }\end{array}$ & 138 & $46.0(28-115)$ & \\
\hline Imam Hatip High School & 73 & $44.0(27-97)$ & \\
\hline Sidıka Hanım High School & 95 & $50.0(27-135)$ & \\
\hline Health Vocational High School & 108 & $50.5(27-116)$ & \\
\hline Trade Vocational High School & 80 & $43.0(28-123)$ & \\
\hline $\begin{array}{ll}\text { Anatolian } & \text { Teacher-Training } \\
\text { High School } & \\
\end{array}$ & 201 & $42.0(27-108)$ & \\
\hline \multicolumn{4}{|l|}{ Paternal education level } \\
\hline Primary school or under & 449 & $48.0(27-135)$ & \multirow[t]{2}{*}{$2.414 ; 0.016$} \\
\hline Secondary school or higher & 571 & $45.0(27-135)$ & \\
\hline \multicolumn{4}{|l|}{ Status of having a lover } \\
\hline Yes & 314 & $60.0(27-135)$ & \multirow[t]{2}{*}{$10.342 ; 0.000$} \\
\hline No & 706 & $42.0(27-127)$ & \\
\hline \multicolumn{4}{|c|}{ The age of getting a mobile phone } \\
\hline$\leq 12$ years & 442 & $51.0(27-135)$ & \multirow{2}{*}{$5.351 ; 0.000$} \\
\hline$\geq 13$ years & 573 & $43.0(27-123)$ & \\
\hline \multicolumn{4}{|l|}{ Use of headphones } \\
\hline Yes & 247 & $51.0(27-127)$ & \multirow{2}{*}{$3.624 ; 0.000$} \\
\hline No & 768 & $45.0(27-135)$ & \\
\hline \multicolumn{4}{|c|}{ Frequency of changing the mobile phone } \\
\hline Yearly or less & 60 & $61.0(29-110)$ & \multirow{2}{*}{$3.778 ; 0.000$} \\
\hline In two years or more & 950 & $45.0(27-135)$ & \\
\hline \multicolumn{4}{|l|}{ Smoking status } \\
\hline No & 891 & $45.0(27-135)$ & \multirow{2}{*}{$6.540 ; 0.000$} \\
\hline Yes & 129 & $63.0(27-135)$ & \\
\hline \multicolumn{4}{|c|}{ Reason for having a mobile phone } \\
\hline SMS & 267 & $55.0(27-135)$ & \multirow{4}{*}{$114.366 ; 0.000$} \\
\hline Phone call & 220 & $39.0(27-106)$ & \\
\hline Other & 122 & $39.5(27-105)$ & \\
\hline For multiple purposes & 411 & $50.0(27-135)$ & \\
\hline \multicolumn{4}{|l|}{ Sleep quality } \\
\hline
\end{tabular}


Öz, F., Arslantaş, D., Buğrul, N., Koyuncu, T., \& Ünsal, A. (2015). Evaluation of problematic use of mobile phones and quality of sleep among high school students. International Journal of Human Sciences, 12(1), 226-235. doi: $10.14687 /$ ijhs.v12i1.3122

\begin{tabular}{|l|l|l|l|}
\hline Satisfactory & 454 & $43.0(27-135)$ & \multirow{2}{*}{$7.297 ; 0.000$} \\
\hline Poor & 566 & $51.0(27-135)$ & \\
\hline
\end{tabular}

Sleep quality decreased with the increasing mean score on PUMP scale, with a positive correlation between PUMP score and decreased sleep quality $(\mathrm{r}=0.26)$. The distribution of the scores on PUMP scale and PSQI is shown in Figure 1.

Figure 1: The distribution of the scores on PUMP scale and PSQI

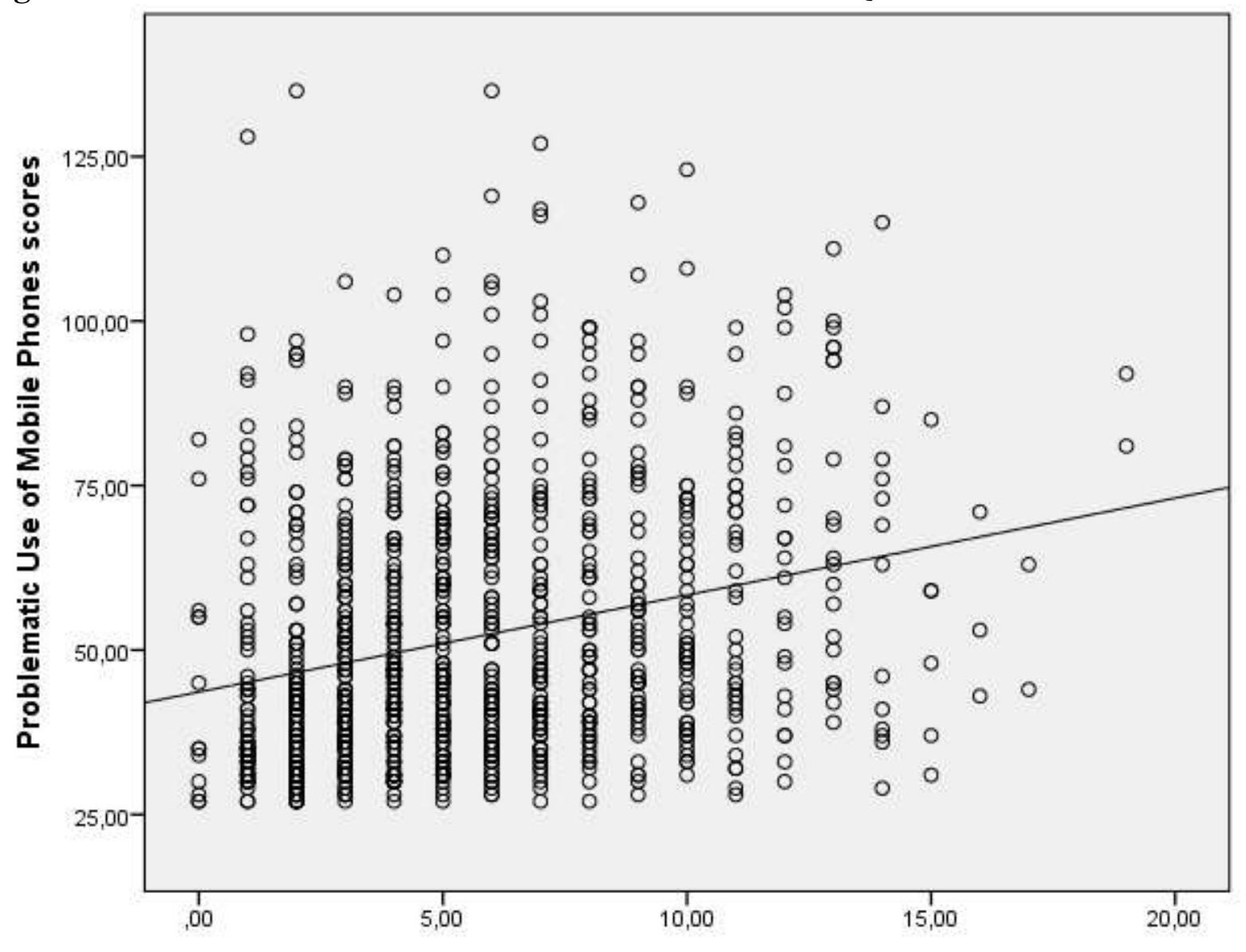

Pittsburgh Sleep Quality Index scores

\section{Discussion}

Because use of mobile phone increases in adolescents with the increasing age, problematic use of the mobile phones is also likely to be increased. In the present study, PUMP scale scores significantly increased with the increasing years of age $(\mathrm{p}<0.05)$. Adriana et al. have also reported higher problematic use of the mobile phones with the increasing age (Bianchi \& Phillips, 2005). 
Öz, F., Arslantaş, D., Buğrul, N., Koyuncu, T., \& Ünsal, A. (2015). Evaluation of problematic use of mobile phones and quality of sleep among high school students. International Journal of Human Sciences, 12(1), 226-235. doi: $\underline{10.14687 / \text { ijhs.v12i1.3122 }}$

Male students had higher mean scores in the present study on PUMP scale $(\mathrm{p}<0.05)$. In the study of Akyurek, it has been stated that male students have higher prevalence of problematic use of mobile phones compared to the female students (Akyürek, 2011).

Low school achievement can be considered to be associated with the excessive use of mobile phones. The scores on PUMP scale was higher in students studying at Industrial Vocational High School and Sidika Hanim High School than compared to the other students $(\mathrm{p}<0.05)$, which may be related to the fact that the score needed to register these two high schools is lower than that are needed for other schools. Yuan et al. have also reported higher prevalence of problematic use of mobile phones among the students with a low school achievement and in those skipping the school frequently (Yang, Yen, Ko, Cheng, \& Yen, 2010).

In the present study, PUMP score was significantly lower in class 9 students compared to the students from other classes $(\mathrm{p}<0.05)$. It may be associated with the facts that this age group usually begins to use mobile phones newly and they usually make new friends. Yuan et al. have also reported lower prevalence of problematic use of mobile phones among class 9 students (Yang et al., 2010).

Fathers with a high education level are considered to be more effective and competent in informing and warning the children for the risks associated with the excessive use of mobile phones. Accordingly, in the present study, PUMP scale score was found to be higher in students whose father's educational level is primary school or under compared to those whose is secondary school or above $(\mathrm{p}<0.05)$. A previous study has also reported similar results (Emilia, 2011).

Because students who have a lover usually need to use multiple functions of the mobile phones (phone call, SMS, internet, video call, and etc.), it can be suggested that these students may spent more time with mobile phone and may have a higher prevalence of problematic use of mobile phones. In the present study, PUMP scale score was higher among the students having alover $(\mathrm{p}<0.05)$. Previous studies have also reported similar results (Green \& Singleton, 2009), (Sara Berg, 2003).

The adolescents getting a mobile phone in a young age may not fulfill the responsibility of using the mobile phone for only the necessary functions of the phone, leading to misuse of the phone and thus increase of the time spent on the phone. Accordingly, in the present study, PUMP scale score was significantly higher in the students who had got a mobile phone at 12 years of age or earlier compared to those who had got at 13 years of age or later $(\mathrm{p}<0.05)$. Similarly, Karaaslan et al. have reported higher duration of mobile phone use among individuals who had got a mobile phone under 14 years of age (Taylor \& Harper, 2003). 
Öz, F., Arslantaş, D., Buğrul, N., Koyuncu, T., \& Ünsal, A. (2015). Evaluation of problematic use of mobile phones and quality of sleep among high school students. International Journal of Human Sciences, 12(1), 226-235. doi: $\underline{10.14687 / \text { ijhs.v12i1.3122 }}$

Individuals spending more time on mobile phone may be aware of the risks associated with the use of mobile phones and may take a variety of measures to minimize these risks. Moreover, individuals using the mobile phones excessively usually use the headphones also for feeling comfortable. The PUMP scale score was found to be significantly higher in students using headphones during the phone call compared to those who do not $(\mathrm{p}<0.05)$. In their study, Tasdemir et al. have studied 412 individuals who were aware of the risks associated with the use of mobile phones and found that, of these individuals, $78.4 \%$ were using the mobile phone by holding directly on the ear and $21.6 \%$ were using the headphones, with the individual using the headphones were spending more time on phone (Taşdemir, 2012). This may be resulted from the fact that individuals using headphones may use the mobile phones excessively because of relying that headphones would eliminate the risks associated the use of mobile phones.

Individuals spending more time on mobile phone usually follow-up the constantly developing technology and may change the mobile phone frequently. In the present study, the individuals spending excessive time on phone were changing their mobile phones frequently, possibly because of following up the technology closely. The PUMP scale score was found to be significantly higher in students changing the mobile phone yearly compared to those changing in two years or more $(\mathrm{p}<0.05)$. In a previous study, students considering the mobile phone as an indispensable technological tool had not wait for wearing out to buy a new phone, with half of them were changing their mobile phones in 3-4 years. Moreover, one third of the students have been found to change their mobile phone before 2 years (Taylor \& Harper, 2003).

Smoking has been considered to also predispose to other addiction types. Accordingly, in the present study, the PUMP scale score was significantly higher in students using cigarette compared to those who do not $(\mathrm{p}<0.05)$. A previous study has also reported an association between the smoking and problematic use of mobile phones (Yang et al., 2010).

In a previous study, adolescents have been found to use the mobile phones mostly for taking or sending text messages with friends, which may also increase the use of mobile phones (Carroll, 2005). Similarly, in the present study, the most commonly used function of the mobile phone is the text messages, with the students using the mobile phone mostly for text messages having higher PUMP scale scores compared to those using for other functions of the mobile phones (phone call, video record, photo, internet, etc.) $(\mathrm{p}<0.05)$. James et al. have also reported that individuals using the mobile phones for text messages are more dependent to the mobile phone (Karim, Darus, \& Hussin, 2006). 
Öz, F., Arslantaş, D., Buğrul, N., Koyuncu, T., \& Ünsal, A. (2015). Evaluation of problematic use of mobile phones and quality of sleep among high school students. International Journal of Human Sciences, 12(1), 226-235. doi: $\underline{10.14687 / \text { ijhs.v12i1.3122 }}$

With the recent advances in mobile phone technology, having a mobile phone is now considered as a symbol of modernity among adolescents. The PUMP scale score in the present study was significantly higher among students whose reason for buying a mobile phone was the consideration that mobile phones enable communication with friends or that mobile phones are a social status tool $(\mathrm{p}<0.05)$. Davie et al. have reported in their study that major reasons for buying a mobile phone was the ease of communication and the adaptation to the social environment, with the higher PUMP scale scores among these groups (Davie, Panting, \& Charlton, 2004) .

With the increasing use of mobile phones, the number of individuals not turning off the mobile phone during the night and holding the mobile phone next to the bed during sleeping also increases. Like the reflex response of a mother to the voice of her baby, adolescents also develop a reflex response to the sound of mobile phone during the night, which possibly deteriorates the sleep quality (White, Buboltz, \& Igou, 2011). In the present study, the PSQI scores increased and sleep quality decreased with the increasing PUMP scale scores (r: 0.26; $<<0.05$ ). Previous studies have also reported similar results (Yang et al., 2010), (White et al., 2011).

\section{Conclusion and recommendations}

Results of the present study suggest that problematic use of mobile phones affects the sleep quality negatively among high school students. Students and their families should be informed about the risks associated with the excessive use of mobile phones. It was also concluded that steering the students to social activities would decrease the mobile phone addiction.

\section{References}

Ağargün, M., Kara, H., \& Anlar, O. (1996). Pittsburgh uyku kalitesi indeksinin geçerliği ve güvenirliği. Türk Psikiyatri Dergisi, 7(2), 107-115.

Akyürek, S. (2011). Çocuklarda İletişim Araçları Bağımlılığı Anket Çalışması Teknik Raporu, http://www.bilgesam.org/Images/Dokumanlar/0-912014040834cocuklardailetisimaraclari.pdf (accessed: May. 15, 2014).

Bianchi, A., \& Phillips, J. G. (2005). Psychological predictors of problem mobile phone use. CyberPsychology \& Behavior, 8(1), 39-51.

Buysse, D. J., Reynolds III, C. F., Monk, T. H., Berman, S. R., \& Kupfer, D. J. (1989). The Pittsburgh Sleep Quality Index: a new instrument for psychiatric practice and research. Psychiatry research, 28(2), 193-213.

Carroll, J. (2005). Drama in the age of digital reproduction. NJ (Drama Australia Journal), 29(1), 15.

Çelik, B. (2011). Cellular telephony in Turkey: A technology of self-produced modernity. European Journal of Cultural Studies, 14(2), 147-161.

Davie, R., Panting, C., \& Charlton, T. (2004). Mobile phone ownership and usage among preadolescents. Telematics and Informatics, 21(4), 359-373. 
Öz, F., Arslantaş, D., Buğrul, N., Koyuncu, T., \& Ünsal, A. (2015). Evaluation of problematic use of mobile phones and quality of sleep among high school students. International Journal of Human Sciences, 12(1), 226-235. doi: $10.14687 /$ ijhs.v12i1.3122

Eggermont, S., \& Van den Bulck, J. (2006). Nodding off or switching off? The use of popular media as a sleep aid in secondary-school children. Journal of Paediatrics and Child Health, 42(7-8), 428-433. doi: DOI 10.1111/j.1440-1754.2006.00892.x

Emilia, P. (2011). Symptoms of the risk of mobile phone addiction and symptoms of mobile phone addiction in Polish young people aged 13 to 24 years measured using Potembska and Pawłowska's Mobile Phone Addiction Assessment Questionnaire.

Green, E., \& Singleton, C. (2009). Mobile connections: an exploration of the place of mobile phones in friendship relations. The Sociological Review, 57(1), 125-144.

Karim, N. S. A., Darus, S. H., \& Hussin, R. (2006). Mobile phone applications in academic library services: a students' feedback survey. Campus-Wide Information Systems, 23(1), 35-51.

Khan, A. F. (2004). Sleep characteristics and sleep deprivation in infants, children and adolescents. In: Who technical Meeting on Sleep and Health. Bonn, Germany. WHO Regional Office for Europe, European centre for Environment Health Bonn Office. 3861.

Özaydın, B. (2010). Teknoloji kültürü ve etik, Süleyman Demirel Üniversitesi, Fen Bilimleri Enstitüsü, basılmamıs yüksek lisans tezi, Isparta.

Özcan, Y. Z., \& Koçak, A. (2003). Research note: A need or a status symbol? Use of cellular telephones in Turkey. European Journal of Communication, 18(2), 241-254.

Öztürk, M. O. (2002). Uyku Bozukluklar, Ruh Sağhlğı ve Bozukluklar (Vol. 9. Basım). Ankara: Feryal Matbaasi.

Sar, A. H., \& Iş1klar, A. (2012). Adaptation of problem mobile phone use scale to Turkish. International Journal of Human Sciences, 9(2), 264-275.

Sara Berg, A. S. T., Richard Harper. (2003). Mobile Phones for the Next Generation: Device Designs for Teenagers. Paper presented at the Proceedings of the 2003 Conference on Human Factors in Computing Systems, Ft. Lauderdale, Florida, USA.

Şenol, V., Soyuer, F., Akça, R. P., \& Argün, M. (2012). Adolesanlarda Uyku Kalitesi ve Etkileyen Faktörler. Kocatepe medical journal, 14, 93-102.

Taşdemir, M. (2012). Üniversitesi Öğrencilerinin Cep Telefonu Kullanmı Hakeıındaki Bilgi, Tutum ve Davramışarı. Paper presented at the Halk Sağlığı Etkinlikleri - HASUDER, 15.Ulusal Halk Sağlı̆̆1 Kongresi, Marmara

Taylor, A. S., \& Harper, R. (2003). The gift of the gab?: A design oriented sociology of young people's use of mobiles. Computer Supported Cooperative Work (CSCW), 12(3), 267-296.

TUIK. (2014). Number of housephones, mobil phones and internet subscribers. http://www.tuik.gov.tr/VeriBilgi.do?alt id=1062 (accessed: Jun. 23, 2014).

White, A. G., Buboltz, W., \& Igou, F. (2011). Mobile phone use and sleep quality and length in college students. International Journal of Humanities and Social Science, 1(18), 51-58.

Yang, Y.-S., Yen, J.-Y., Ko, C.-H., Cheng, C.-P., \& Yen, C.-F. (2010). The association between problematic cellular phone use and risky behaviors and low self-esteem among Taiwanese adolescents. BMC Public Health, 10(1), 217. 